Note

\section{Expression of the Two 130-kDa Protein Genes of Bacillus thuringiensis var. israelensis in Bacillus subtilis}

\author{
Ken-ichi Yoshida, Kikuo Sen,* \\ Hiroshi SAKaI and Tohru Komano \\ Laboratory of Biochemistry, Department of \\ Agricultural Chemistry, Kyoto University, \\ Kyoto 606, Japan \\ * Department of Bioscience and Biotechnology, \\ Faculty of Agriculture, Shinshu University. \\ Minami-minowa, Nagano 399-45, Japan
}

Received April 10, 1989

Bacillus thuringiensis var. israelensis (BTI) produces parasporal crystal proteins known as $\delta$-endotoxin during sporulation. The crystal proteins contain $130-\mathrm{kDa}$ proteins which are toxic to mosquito larvae. ${ }^{1)}$ We have reported cloning and nucleotide sequencing of the genes for the two homologous $130 \mathrm{kDa}$ proteins, ISRH3 and ISRH $4,{ }^{2)}$ and that the gene products synthesized in Escherichia coli cells were toxic to mosquito larvae. ${ }^{3)}$ Several investigators have reported cloning of the $130-\mathrm{kDa}$ protein genes of $B T I$ and the insecticidal activities of the cloned gene products in $E$. coli or Bacillus subtillis. ${ }^{49)}$ However no one has ever succeeded in having the genes for both the two $130-\mathrm{kDa}$ proteins expressed in $B$. subtilis depending upon their own transcriptional promoters. In this paper, we report the expression of the genes for ISRH 3 and ISRH4 in B. subtilis cells depending on their own transcriptional promoters, and the insecticidal ac- tivity of the gene products.

A 5.2-kb HindIII fragment coding for ISRH3 on the plasmid $\mathrm{pBGH} 3^{2)}$ was subcloned into the HindIII site of the $B$. subtilis vecter $\mathrm{pC} 194^{10}$ to construct $\mathrm{pCH} 3$ (Fig. 1). Likewise a $5.0-\mathrm{kb}$ HindIII fragment coding for ISRH4 on the plasmid $\mathrm{pBGH} 4^{2)}$ was subcloned into the HindIII site of pCl94 to construct plasmid pCH4 (data not shown). The ISRH3 gene on the plasmid pCH3, ard the ISRH4 gene on the plasmid $\mathrm{pCH} 4$ are expected to be transcribed from their own promoters.

An enzyme-linked immunosorbent assay indicated that the ISRH3 and ISRH4 proteins were produced in $B$. subtilis $\mathrm{LI}$ cells harboring $\mathrm{pCH} 3$ and $\mathrm{pCH} 4$, respectively, during both vegetation and sporulation (Fig. 2). The amount of ISRH3 and ISRH4 proteins increased during sporulation (Fig. 2). This result showed that the expression level of the genes for the $130-\mathrm{kDa}$ proteins of $B T I$ was elevated under the sporulational regulation in B. subtilis, and coincided with the phenomenon that the expression level of the genes was extremely elevated during sporulation in $B T I$. It is interesting that promoters of the genes for $130-\mathrm{kDa}$ proteins of $B T I$ are functional in $B$. subtilis, but the expression level during sporulation in $B$. subtilis was not as high as it was in $B T I$. Since the ISRH3 gene on $\mathrm{pCH} 3$ and the ISRH4 gene on pCH4 lacked the hair-pin loop structures that might act as a transcriptional terminator in their $3^{\prime}$-flanking regions, their expression level might be limited.

Crude extracts of $B$. subtilis cells carrying pCH3 and pCH4, which were prepared during vegetation or sporulation, were toxic to mosquito larvae, but those of $B$. subtilis cells carrying the vector pC194 were not (Table I). And the extracts prepared from the cells during sporulation were more toxic than those during vegetation (Table I). The results indicated that both ISRH3 and ISRH4 proteins produced in $B$. subtilis cells were mosquitocidal, and that their amounts increased during sporulation. This coincided with the evidence that the expression level of the

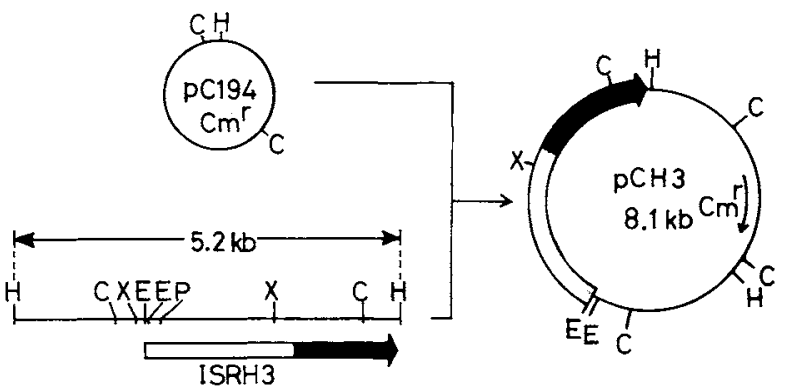

Fig. 1. Construction of the Plasmid Encoding the Gene for $130-\mathrm{kD}$ a Protein (ISRH3) of BTI.

The cloned DNA fragments containing the ISRH3 gene was derived from BTI HD522. ${ }^{2)}$ Plasmid pC194 was used as a vector. For clarity not all the restriction sites are shown. The thick arrow indicates the direction of transcription and the coding stretch of ISRH3. The solid area of the thick arrow indicates a stretch where ISRH3 and ISRH4 are identical in their amino acid sequences. The recombinant plasmid pCH3 was used to transform $B$. subtilis $\mathrm{L} 1$ by the protoplast method. ${ }^{11)} \mathrm{H}$, HindIII; C, ClaI; E, EcoRI; P, PstI; X, XbaI. 


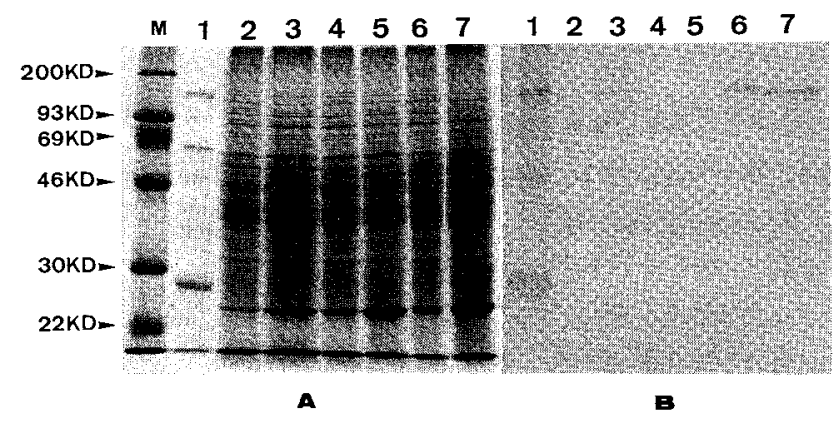

Fig. 2. Production of the $130-\mathrm{kDa}$ Proteins (ISRH3 and ISRH4) of BTI in B. subtilis.

An SDS-polyacrylamide gel electrophoregram (A) and a corresponding protein immunoblot (B) are shown. Lane 1 , crystal $(10 \mu \mathrm{g})$. Each lanes $2 \sim 7$ contained $50 \mu \mathrm{g}$ of protein extracts; $B$. subtilis Ll carrying pC194 (lanes 2 and 5), pCH3 (lanes 3 and 6), pCH4 (lanes 4 and 7). Lanes $2 \sim 4$ contained the protein extracts prepared from the cells during vegetation and lanes $5 \sim 7$ protein extracts prepared from the cells during sporulation (see Table I). Lane M contained size marker proteins. KD, kilodalton.

Table I. Insecticidal Activity on Mosquito Larvae OF THE PRoteIn Extracts of $B$. subtilis li Cells Carrying Plasmids

\begin{tabular}{ccc}
\hline & \multicolumn{2}{c}{$\mathrm{LC}_{50}(\mu \mathrm{g} / \mathrm{ml})^{b}$} \\
\cline { 2 - 3 } Test sample $^{a}$ & $24 \mathrm{hr}$ & $48 \mathrm{hr}$ \\
\hline $\mathrm{L} 1 / \mathrm{pC194}$ & - & $-^{c}$ \\
$\mathrm{pCH} 3$ & 217 & 149 \\
$\mathrm{pCH} 4$ & 211 & 203 \\
$\mathrm{pC194}$ & - & $-{ }^{c}$ \\
pCH3* & 70 & 58 \\
pCH4* & 83 & 54 \\
\hline
\end{tabular}

a Cells of B. subtilis L1 carrying plasmids were cultured at $30^{\circ} \mathrm{C}$ until $\mathrm{OD}_{610}=0.5$ (vegetation), or for $30 \mathrm{hr}$ (sporulation; indicated by ${ }^{*}$ ) in PY broth ${ }^{12}$ ) containing $10 \mu \mathrm{g} / \mathrm{ml}$ chloramphenicol. The cells were harvested and washed with $1 \mathrm{M} \mathrm{NaCl}$ by centrifugation. Cell pellets were suspended in $0.1 \mathrm{M} 2-$ mercaptoethanol and ultrasonicated. The suspension was mixed with an equal volume of $0.2 \mathrm{M}$ glycine- $\mathrm{NaOH}\left(\mathrm{pH} \mathrm{10.5)}\right.$, incubated at $37^{\circ} \mathrm{C}$ for $3 \mathrm{hr}$, adjusted to $\mathrm{pH} 7.5$, and centrifuged. Proteins in the supernatant were precipitated with $50 \%$-saturated ammonium sulfate. The precipitates were suspended in $0.1 \mathrm{M}$ glycine- $\mathrm{NaOH}(\mathrm{pH} 10.5)$ containing $0.05 \mathrm{M}$ 2-mercaptoethanol, dialyzed against Dulbecco's PBS (without $\mathrm{Ca}^{2+}$ and $\mathrm{Mg}^{2+}$ ), ${ }^{3)}$ and centrifuged. Mosquito larvicidal activity of the supernatant was analyzed by the method of Schne $11^{13}$ and details were previously described. ${ }^{3+}$ The larvae were fed with the protein extract and mortality was scored after $24 \mathrm{hr}$ and $48 \mathrm{hr}$.

${ }^{b} \mathrm{LC}_{50}$ : Lethal concentration $(50 \%$ end point) is shown at a final concentration of the protein extract.

c At the concentration of $200 \mu \mathrm{g} / \mathrm{ml}$ of the protein extract, no larvae died. genes was elevated during sporulation in B. subtilis. We could not decide which was more toxic, ISRH3 or ISRH4 protein, because we did not know the exact amount of toxic proteins in the extracts. Though Ward and Ellar ${ }^{5)}$ have recently reported that the purified ISRH3-type protein is more toxic than the purified ISRH4-type protein, ISRH3 and ISRH4 proteins seemed to have almost the same level of toxicity in our investigation.

Acknowledgments. We wish to thank Dr. H. Ohkawa of the Sumitomo Chemical Co., Ltd., Japan for providing us with eggs of the mosquito Culex pipiens, and IgG against the crystal of BTI. This work was supported in part by a Grant-in-Aid for Scientific Research from the Ministry of Education, Science and Culture of Japan and from the Association for the Advancement of Science of Nagano Prefecture.

\section{References}

1) L. J. Goldberg and J. Margalit, Mosquito News, 37, 355 (1977).

2) K. Sen, G. Honda, N. Koyama, M. Nishida, A. Neki, H. Sakai, M. Himeno and T. Komano, Agric. Biol. Chem., 52, 873 (1988).

3) K. Sen, A. Neki, M. Nishida, G. Honda, Y. Ogura, H. Sakai, M. Himeno and T. Komano, Agric. Biol. Chem., 52, 1593 (1988).

4) E. S. Ward and D. J. Ellar, Nucl. Acids Res., 15, 7195 (1987).

5) E. S. Ward and D. J. Ellar, J. Bacteriol., 170, 727 (1988).

6) C. Angsuthanasombat, W. Chungjatupornchai, S Kertbundit, P. Luxananil, C. Settasatian, P. Wilairat and S. Panyim, Mol. Gen. Genet., 208, 384 (1987).

7) S. Tuhgpradubkul, C. Sattasatien and S. Panyim, 
Nucl. Acids Res., 16, 1637 (1988).

8) V. Sekar and B. C. Carlton, Gene, 33, 151 (1985).

9) C. Bourgouin, A. Delecluse, J. Ribier, A. Klier and G. Rapoport, J. Bacteriol., 170, 3575 (1988).

10) S. Horinouchi and B. Wislum, J. Bacteriol., 150, 1513 (1982).
11) T. Akamatsu and J. Sekiguchi, Agric. Biol. Chem., 46, 1617 (1982).

12) K. Bernhard, H. Schrempf and W. Goebel, J. Bacteriol., 133, 897 (1975).

13) D. Schnell, M. A. Pfannenstiel and K. W. Nickerson, Science, 223, 1191 (1984). 